\section{Growth Substance, Light, Fertilizer, and Misting Regulate Propagation and Growth of Golden Pothos}

\author{
Yin-Tung Wang ${ }^{1}$ \\ Texas A\&M University Agricultural Research and Extension Center, \\ 2415 East Highway 83, Weslaco, TX 78596
}

Additional index words. foliage plant, cutting, Epipremnum aureum

\begin{abstract}
Foliar application of 500 or $1000 \mathrm{mg}$ BA or PBA/liter to stock plants of golden pothos [Epipremnum aureum (Linden \& Andre) Bunt.] induced axillary bud elongation but did not promote growth of cuttings taken from these stock plants. Cuttings from plants treated with $\mathbf{B A}+\mathbf{G A}_{4+7}$, each at 1000 mg-liter ${ }^{-1}$, died. Plants grown under $1000 \mu \mathrm{mol} \cdot \mathrm{s}^{-1} \cdot \mathrm{m}^{-2}$ had more but smaller leaves than those under 420 $\mu \mathrm{mol} \cdot \mathrm{s}^{-1} \cdot \mathrm{m}^{-2}$. Cuttings produced under the higher light level grew more rapidly. Leaf area increased while stem length decreased as Osmocote slow-release fertilizer $(18 \mathrm{~N}$ 2.6P-10K) increased from 4 to $16 \mathrm{~kg} \cdot \mathrm{m}^{-3}$. A $24 \mathrm{~N}-3.5 \mathrm{P}-13.3 \mathrm{~K}$ water-soluble fertilizer applied at the rate of $0.42 \mathrm{~g} / 500 \mathrm{ml}$ weekly produced the best plants and resulted in the best cutting growth. Cuttings taken from stock plants receiving Osmocote at 4 $\mathrm{kg} \cdot \mathrm{m}^{-3}$ grew slower than those produced at other rates. Placement of cuttings in a mist-propagation bed for 1 or more weeks resulted in an accelerated growth rate relative to nonmisted cuttings. Chemical names used: $\mathrm{N}$-(phenylmethyl)-1H-purin-6amine (BA); N-(phenylmethyl)-9-(tetrahydro-2H-pyran-2-yl)-9H-purin-6-amine (PBA);

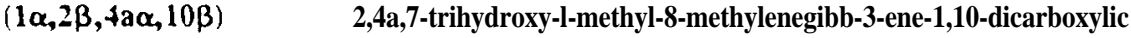
acid 1,-4a-lactone $\left(\mathbf{G A}_{4+7}\right)$.
\end{abstract}

Most tropical foliage plants are produced in soilless media under reduced light intensities. A carefully controlled fertilization program ensures good plant growth. Good quality Syngonium podophyllum plants were produced in a greenhouse with 5 to $19.5 \mathrm{~g}$ of Osmocore slow-release fertilizer per IS-cm pot, with reductions in plant growth at higher rates (Chase and Poole, 1987). These authors also observed that plants had lower quality when produced under 200 than under $700 \mu \mathrm{mols} \mathrm{s}^{-1} \cdot \mathrm{m}^{-2}$ photosynthetic photon flux (PPF). Nephrolepsis exaltara 'Compacta' produced the greatest dry weight with a liquid fertilizer $(20 \mathrm{~N}-0.8 \mathrm{P}-16.6 \mathrm{~K})$ at a rate of $0.75 \mathrm{~g} \cdot$ iter $^{-1}$ or with $9.5 \mathrm{~kg} \cdot \mathrm{m}^{-3}$ Osmocote (19N-2.5P-8.3K) (Gilliam et al., 1983). High quality peperomia was produced with $2.5 \mathrm{~g}$ Osmocote per $10-\mathrm{cm}$ pot (19N-3P-10K) (Chase and Poole, 1984).

Environmental conditions under which stock plants are grown affect the growth of cuttings taken from these plants. Proper lighting enhanced the yields and subsequent

Received for publication 4 Dec. 1989. The cost of publishing This paper was defrayed in part by the payment of page charges. Under postal regutations, this paper therefore must be hereby marked adverisement solely to indicate this fact..

${ }^{1}$ Associate Professor. growth of cuttings (Anderson and Carpenter, 1974; Bertram et al., 1989; Vetanovetz and Peterson, 1985). Increasing shade level from $0 \%$ to $60 \%$ decreased the number and weight of cuttings produced by several Codiaeum variegatum cultivars, but cutting yields increased with higher fertilizer levels (Conover and Poole, 1983). However, there was no difference in the growth of Syngonium podophyllum 'White Butterfly' cuttings pro(Wang and Boogher, 1987).

Epipremnum aureum (pothos) is economically the most important foliage species being produced in Florida (Florida Dept. of Agr., duced under 650 or $1200 \mu \mathrm{mol} \cdot \mathrm{s}^{-1} \cdot \mathrm{m}^{-2}$

${ }^{\mathrm{z}}$ Dashed line $=$ all plants dead.
1989) and possibly the other major states that produce foliage plants. Although general production guidelines are available (Poole et al., 1984, 1985) and several studies have been conducted (Poole and Conover, 1988; Wang, 1987; Wang and Boogher, 1988) to optimize production, more specific information on cultural practices is needed for the most efficient production of this species. Treating cuttings of golden pothos with BA did not promote cutting growth (Wang, 1987); however, it remained unknown whether treating stock plants with growth regulators would promote cutting growth. The objective of this study was to determine the growth and propagation of golden pothos in response to applications of growth regulators and fertilizers, light levels, and misting.

Hormonal effect on cutting growth (Expt. I). Golden pothos in 4-liter hanging baskets were grown under $73 \%$ light-exclusion fabric. $\mathrm{BA}$ or $\mathrm{PBA}$ each at 500 or 1000 $\mathrm{mg} \cdot \mathrm{liter}^{-1}$, the combination of BA and GA.,,, each at $1000 \mathrm{mg}^{-1 i t e{ }^{-1}}$ (Promolin formulation, Abbott Laboratories, North Chicago, Ill.) or water (control), all with Tween 20 at the rate of $1 \mathrm{ml} \cdot$ liter $^{-1}$, was sprayed on the foliage of two baskets per treatment. After 3 weeks, lengths of the axillary buds between the second and sixth nodes were recorded on six vigorous shoots from each treatment. Preparation of cuttings followed recommendations in previously published reports (Wang, 1987; Wang and Boogher, 1988). Single-node leaf-bud cuttings (used in this and all subsequent experiments) were taken from these nodes, planted one per 0.5liter pot filled with a peat-lite potting mix (Sunshine No. 1, Fisons Western, Vancouver, B.C.), and placed in a mist propagation bed. Misting time was $5 \mathrm{sec}$ every $5 \mathrm{~min}$ during the daylight hours. Date on which the first leaf of each cutting unrolled was recorded. Cuttings were removed from the mist bed after 3 weeks, placed on a greenhouse bench with $340 \mu \mathrm{mol} \cdot \mathrm{s}^{-1} \cdot \mathrm{m}^{-2}$ maximum

Table 1. Effect of foliar application of growth regulators to stock plants of Epipremnum aureum on the length of the axillary buds and on cutting growth during 12 weeks (Expt. 1).

\begin{tabular}{|c|c|c|c|c|c|c|}
\hline \multirow[b]{2}{*}{$\begin{array}{l}\text { Treatment } \\
\left(\mathrm{mg} \cdot \text { liter }^{-1}\right)\end{array}$} & \multirow{2}{*}{$\begin{array}{l}\text { Axillary } \\
\text { bud } \\
\text { length } \\
\text { (cm) }\end{array}$} & \multicolumn{5}{|c|}{ Cutting growth } \\
\hline & & $\begin{array}{l}\text { First leaf } \\
\text { unfolding } \\
\text { (days) }\end{array}$ & $\begin{array}{l}\text { Stem } \\
\text { length } \\
(\mathrm{cm})\end{array}$ & $\begin{array}{l}\text { Leaf } \\
\text { no. }\end{array}$ & $\begin{array}{l}\text { Leaf } \\
\text { arca } \\
\left(\mathrm{cm}^{2}\right)\end{array}$ & $\begin{array}{c}\text { Shoor } \\
\text { frcsh w } \\
\text { (g) }\end{array}$ \\
\hline$\overline{\text { Control }}$ & 0.4 & 26.3 & 15.7 & 4.8 & 142 & 9.2 \\
\hline BA 500 & 1.4 & 25.8 & 8.4 & 3.8 & 111 & 8.4 \\
\hline 1000 & 1.6 & 24.8 & 7.4 & 3.8 & 113 & 7.4 \\
\hline PBA 500 & 1.4 & 19.5 & 15.9 & 5.2 & 151 & 9.6 \\
\hline 1000 & 1.7 & 21.3 & 11.2 & 4.2 & 136 & 8.3 \\
\hline$B A+G A-1000$ & 3.1 & $\ldots \alpha^{2}$ & $\ldots$ & $\ldots$ & $\ldots$ & $\cdots$ \\
\hline $\mathrm{LSD}_{41 \mathrm{~s}}$ & 0.4 & 3.4 & 2.8 & 0.6 & 22 & 1.5 \\
\hline
\end{tabular}


Table 2. Effect of light level and fertilizer rate and type on the growth of Epipremnum aureum during 4 months (Expt. 2).

\begin{tabular}{|c|c|c|c|c|}
\hline Treatment & Leaf no. & $\begin{array}{l}\text { Leaf areay } \\
\left(\mathrm{cm}^{2}\right)\end{array}$ & $\begin{array}{c}\text { Stem length } \\
(\mathrm{cm})\end{array}$ & $\begin{array}{l}\text { Shoot } \\
\text { fresh w } \\
\text { (g) }\end{array}$ \\
\hline \multicolumn{5}{|l|}{ Light $\left(\mu \mathrm{mol} \cdot \mathrm{s}^{-1} \cdot \mathrm{m}^{-2}\right)$} \\
\hline 420 & 13.7 & 63.0 & 74.9 & 49.7 \\
\hline 1000 & 14.7 & 54.7 & 77.1 & 47.6 \\
\hline Significance ${ }^{x}$ & $\because$ & $\cdots$ & NS & NS \\
\hline \multicolumn{5}{|l|}{ Fertilizer } \\
\hline \multicolumn{5}{|l|}{ Osmocote $\left(\mathrm{kg} \cdot \mathrm{m}^{-3}\right)$} \\
\hline 4 & 14.1 & 51.3 & 78.8 & 44.5 \\
\hline 8 & 14.1 & 59.4 & 75.9 & 48.6 \\
\hline 12 & 14.1 & 59.5 & 73.0 & 48.4 \\
\hline 16 & 13.9 & 61.4 & 68.2 & 47.3 \\
\hline Significance & NS & $\mathrm{L}^{*} \mathrm{Q}^{*}$ & $L^{*}$ & NS \\
\hline \multicolumn{5}{|l|}{$\begin{array}{l}\text { Soluble fertilizer } \\
\left(\mathrm{SF}, \mathrm{kg} \cdot \mathrm{m}^{-3}\right)^{\mathrm{w}}\end{array}$} \\
\hline 2.8 & 14.9 & 62.5 & 83.9 & 54.6 \\
\hline SF vs. Osmocotev & $\cdots$ & $*$ & $*$ & $*$ \\
\hline
\end{tabular}

${ }^{\mathrm{z}}$ No significant interaction between light level and fertilizer rate.

${ }^{\mathrm{y}}$ The uppermost, fully expanded leaf.

${ }^{* * *}$ and ${ }^{*}$, significant at $\alpha=0.01$ and 0.05 , respectively. NS $=$ nonsignificant. $\mathrm{L}$ and $\mathrm{Q}=$ linear and quadratic response, respectively.

${ }^{\mathrm{w}}$ Total $24 \mathrm{~N}-3.5 \mathrm{P}-13.3 \mathrm{~K}$ fertilizer applied during a 10 -week period.

'Significance determined by single-degree-of-freedom contrast.

Table 3. Growth of Epipremnum aureum cuttings during 87 days as a function of light level and fertilizer rate and type applied 10 stock plants (Expt. 2).'

\begin{tabular}{|c|c|c|c|c|}
\hline \multirow[b]{2}{*}{$\begin{array}{l}\text { Previous } \\
\text { treatment on } \\
\text { stock plants }\end{array}$} & \multicolumn{4}{|c|}{ Culting growth } \\
\hline & $\begin{array}{l}\text { Leaf } \\
\text { no. }\end{array}$ & $\begin{array}{c}\text { Total leaf } \\
\text { area } \\
\left(\mathrm{cm}^{2}\right)\end{array}$ & $\begin{array}{l}\text { Stem length } \\
(\mathrm{cm})\end{array}$ & $\begin{array}{c}\text { Shoot } \\
\text { fresh w } \\
\text { (g) }\end{array}$ \\
\hline \multicolumn{5}{|l|}{ Light $\left(\mu \mathrm{mol} \cdot \mathrm{s}^{-1} \cdot \mathrm{m}^{-2}\right)$} \\
\hline 420 & 4.4 & 162 & 9.5 & 10.0 \\
\hline 1000 & 6.2 & 217 & 14.5 & 12.9 \\
\hline Significancey & $\cdots$ & $*$ & $\cdot \cdot$ & $\because$ \\
\hline \multicolumn{5}{|l|}{ Fertilizer } \\
\hline \multicolumn{5}{|l|}{ Osmocote $\left(\mathrm{kg} \cdot \mathrm{m}^{-3}\right)$} \\
\hline 4 & 4.7 & 150 & 9.2 & 8.6 \\
\hline 8 & 5.8 & 211 & 13.6 & 12.4 \\
\hline 12 & 5.1 & 186 & 11.9 & 11.3 \\
\hline 16 & 5.1 & 198 & 11.6 & 12.3 \\
\hline Significance & $0^{*}$ & $L^{*} Q^{*}$ & $Q^{*}$ & $L^{*} \mathrm{Q}^{*}$ \\
\hline \multirow{2}{*}{\multicolumn{5}{|c|}{$\begin{array}{l}\text { Soluble fertilizer } \\
\left(\mathrm{SF}, \mathrm{kg} \cdot \mathrm{m}^{-3}\right)^{x}\end{array}$}} \\
\hline & & & & \\
\hline 2.84 & 5.8 & 203 & 13.7 & 12.5 \\
\hline SF vs. Osmocote* & $\cdots$ & NS & • & NS \\
\hline
\end{tabular}

${ }^{\mathrm{z}}$ No significant interaction between light level and fertilizer rate.

$\mathrm{y}_{* *}$ and ${ }^{*}$, significant at $\alpha=0.01$ and 0.05 , respectively. $\mathrm{NS}=$ nonsignificant. $\mathrm{L}$ and $\mathrm{Q}=$ linear and quadratic response, respectively.

${ }^{\mathrm{x}}$ Total $24 \mathrm{~N}-3.5 \mathrm{P}-13.3 \mathrm{~K}$ fertilizer applied during production of stock plants.

${ }^{\mathrm{w}}$ Significance determined by single-degree-of-freedom contrast.

PPF, and fertilized weekly with 24N-3SP13.3K water-soluble fertilizer (W.R. Grace, Foglesville, Pa.) at $0.84 \mathrm{~g} \cdot$ liter $^{-1}$. Plants were evaluated for leaf number, total leaf area, stem length, and fresh weight after an additional 9 weeks of growth. There were five pots each with a single plant as an experimental unit and treatments were replicated six times in a randomized complete-block (RCB) design. The least significant difference was used to compare any treatment effect with the control.

Axillary bud length increased after applications of $\mathrm{BA}, \mathrm{PBA}$, or the combination of $\mathrm{BA}$ and $\mathrm{GA}_{4+7}$, on stock plants, with the latter most effective (Table 1). Spraying the mixture of $\mathrm{BA}$ and $\mathrm{GA}_{4+7}$, on stock plants resulted in the complete loss of cuttings during propagation. PBA at both concentrations row leaves were produced. GA has been reported to induce flowering in several aroid species (Harbaugh and Wilfret, 1979; Henny, 1980). Cuttings receiving BA and $\mathrm{GA}_{4+7}$, may have died due to inflorescence development or hormonal imbalance and a lack of roots. Syngonium podophyllum plants derived from cuttings treated with PBA before planting had weak root systems (Wang and Boogher, 1987) and cuttings treated with GA died (Y.T.W., unpublished data).

Light and fertilizer effect on stock plant and cutting growth (Expt. 2). Cuttings were taken from stock plants cultured as above and planted three in a 1.5 -liter pot. The potting mix consisted of 2 peat moss : 2 bark : 1 perlite (by volume). After being held in a mist propagation bed for 3 weeks, half of the plants were placed in a greenhouse with $420 \mu \mathrm{mol} \cdot \mathrm{s}^{-1} \cdot \mathrm{m}^{-2}$ maximum PPF and the others in one with $1000 \mu \mathrm{mol} \cdot \mathrm{s}^{-1} \cdot \mathrm{m}^{-2} \mathrm{PPF}$. Treatments included applying $18 \mathrm{~N}-2.6 \mathrm{P}-10 \mathrm{~K}$ Osmocote fertilizer at $6,12,18$, or 24 g per pot (equivalent to medium at $4,8,12$, or 16 $\mathrm{kg} \cdot \mathrm{m}^{-3}$ ) on the medium surface 6 weeks after removal from the mist bed. Plants in another treatment were fertilized weekly with $500 \mathrm{ml}$ of water containing $0.42 \mathrm{~g} 24 \mathrm{~N}-3.5 \mathrm{P}-13.3 \mathrm{~K}$ soluble fertilizer during the experiment (a total amount of $2.8 \mathrm{~kg} \cdot \mathrm{m}^{-3}$ ). Plants were irrigated two or three times each week when the medium surface became dry. Plants were evaluated 4 months after planting for number of leaves per stem, stem length, area of the uppermost, fully expanded leaf, and shoot fresh weight. Fertilizer rates (considered as the subplot) within each light level (main plot) were arranged in a RCB design with 10 replications.

Cuttings from plants receiving all the previous treatments were planted four per 1.5 liter pot, placed in a mist bed for 3 weeks, and later moved to a greenhouse receiving $420 \mu \mathrm{mols}{ }^{-1} \cdot \mathrm{m}^{-2}$ maximum PPF. All plants were given water-soluble $24 \mathrm{~N}-3.5 \mathrm{P}-13.3 \mathrm{~K}$ fertilizer weekly as previously described. Data were collected on leaf number, total leaf area, stem length, and shoot fresh weight 87 days after planting. Plants were arranged in a splitplot design using a single pot as an experimental unit, with the previous light level as the main plot and the fertilizer treatment as the subplot, replicated 10 times. Linear and quadratic regression analyses were used for determining the effect of Osmocote rate on plant growth. The difference between the water-soluble fertilizer and Osmocote was determined by single-degree-of-freedom contrast.

Increasing the light intensity from 420 to $1000 \mu \mathrm{mols}{ }^{-1} \cdot \mathrm{m}^{-1}$ increased leaf production but decreased individual leaf size (Table 2). Stem length and shoot fresh weight were unaffected. Syngonium podophyllum grown under $200 \mu \mathrm{mol} \cdot \mathrm{s}^{-1} \cdot \mathrm{m}^{-2}$ had $32 \%$ fewer leaves and $27 \%$ less weight than those produced under $700 \mu \mathrm{mol} \cdot \mathrm{s}^{-1} \cdot \mathrm{m}^{-2}$ (Chase and Poole, 1987). In this current study, the low light intensity of $420 \mu \mathrm{mol} \cdot \mathrm{s}^{-1} \cdot \mathrm{m}^{-2} \mathrm{might}$ have provided adequate energy for satisfactory growth. Osmocote rate had no effect on leaf number or shoot fresh weight. A weekly 
Table 4. Effect of misting time on the growth of axillary shoots of Epipremnum aureum cuttings during 14 weeks (Expt. 3).

\begin{tabular}{|c|c|c|c|c|c|}
\hline $\begin{array}{l}\text { Weeks } \\
\text { in mist } \\
\text { bed }\end{array}$ & $\begin{array}{c}\text { First leaf } \\
\text { unfolding } \\
\text { (days) }\end{array}$ & $\begin{array}{c}\text { Leaf } \\
\text { no. }\end{array}$ & $\begin{array}{c}\text { Total } \\
\text { leaf area } \\
\left(\mathrm{cm}^{2}\right)\end{array}$ & $\begin{array}{l}\text { Shoot } \\
\text { length } \\
(\mathrm{cm})\end{array}$ & $\begin{array}{c}\text { Fresh } \\
\text { wt } \\
(\mathrm{g}) \\
\end{array}$ \\
\hline 0 & 28.8 & 5.1 & 235 & 12.1 & 12.1 \\
\hline 1 & 21.7 & 7.2 & 295 & 22.2 & 18.9 \\
\hline 2 & 20.2 & 7.5 & 314 & 25.5 & 20.2 \\
\hline 3 & 19.3 & 8.4 & 299 & 30.4 & 20.3 \\
\hline 4 & 20.3 & 8.8 & 305 & 35.3 & 20.6 \\
\hline 5 & 20.6 & 8.5 & 286 & 33.3 & 19.5 \\
\hline Significance ${ }^{2}$ & $\mathrm{~L}^{*} \mathrm{Q}^{* *}$ & $\mathrm{~L}^{* *} \mathrm{Q}^{* *}$ & $L^{*} \mathrm{Q}^{* *}$ & $L=Q^{*}=$ & $L^{* *} Q^{* *}$ \\
\hline
\end{tabular}

${ }^{\mathrm{z}} \mathrm{L}$ and $\mathrm{Q}=$ linear and auadraric response, rcspectively.

** Significant at $\alpha=0.01$.

application of the water-soluble fertilizer at $0.42 \mathrm{~g} / \mathrm{pot}$ gave results as good as or better than Osmocote. Osmocote at the rate of 4 $\mathrm{kg} \cdot \mathrm{m}^{-3}$ resulted in smaller leaves than did higher levels. Stem length decreased as rate of Osmocote increased. Water-soluble fertilizer produced longer stems and greater fresh weights than any rate of Osmocote.

Cuttings from golden pothos produced under $420 \mu \mathrm{mol} \cdot \mathrm{s}^{-1} \cdot \mathrm{m}^{-2}$ grew more slowly than cuttings from plants produced under 1000 $\mu \mathrm{mol} \cdot \mathrm{s}^{-1} \cdot \mathrm{m}^{-2}$ (Table 3$)$. Osmocote at the rate of $8 \mathrm{~kg} \cdot \mathrm{m}^{-3}$ and the water-soluble fertilizer produced plants with the greatest number of leaves and the longest stems. Total leaf area and shoot fresh weight were mostly unaffected by fertilization except they were smaller at the Osmocote rate of 4 $\mathrm{kg} \cdot \mathrm{m}^{-3}$.

Getting growth in response to misting (Expt. 3). Cuttings of golden pathos were taken from the apical second to seventh nodes of stock plants, grown under 420 $\mu \mathrm{mol} \cdot \mathrm{s}^{-1} \cdot \mathrm{m}^{-2}$ maximum PPF, and fertilized weekly as described above. Cuttings were planted, one per 0.5-liter pot, in Sunshine Mix No. 1. The cuttings, except the controls, which were placed directly on a greenhouse bench after planting, were placed in a mist propagation bed with a mist interval of $5 \mathrm{sec}$ every $5 \mathrm{~min}$. One-fifth of the cuttings were removed after $1,2,3,4$, and 5 weeks and placed on the bench noted above. All plants on the greenhouse bench received water-soluble fertilizer weekly as already described. Date of first leaf unfolding was recorded for each plant. Leaf number, total leaf area, stem length, and fresh weight of the shoot were recorded 14 weeks after planting. Treatments, both in the mist bed and on the greenhouse bench, were arranged in a RCB design. Each treatment had five pots, each with a single plant, as an experimental unit replicated six times. Data were subjected to regression analysis.

Misting cuttings for at least 1 week shortened the time required to produce the first leaves (Table 4), but longer periods had little additional effect. Leaf number and shoot length increased as misting time increased. Previous findings demonstrate accelerated root development resulted in faster shoot growth (Wang and Boogher, 1988). Misting pathos cuttings might have facilitated the rapid development of roots and reduced the internal water stress, resulting in enhanced growth rates. Total leaf area and shoot fresh weight did not become greater for cuttings misted 3 weeks or longer.

Results from these experiments and another study (Wang, 1987) suggest cytokinin or GA application to stock plants or cuttings does not benefit axillary shoot growth on cuttings of golden pathos. Although 420 $\mu \mathrm{mol} \cdot \mathrm{s}^{-1} \cdot \mathrm{m}^{-2}$ PPF appeared to be adequate for finished plant production, stock plants require higher light levels for optimum cutting production and subsequent growth. The use of a water-soluble fertilizer may lower production cost and result in less environmental contamination due to the reduced amount of fertilizer in the run-off water when compared to the amount of Osmocote required to produce comparable growth.

\section{Literature Cited}

Anderson, G.A. and W.J. Carpenter. 1974. High intensity supplementary lighting of chrysanthe- mum stock plants. HortScience 9:58-60.

Bertram, L., R. Moe, and A.S. Anderson. 1989. Supplementary irradiance to stock plants regulates root formarion and growth in top cuttings of a Begonia Elatior-hybrid. Scientia Hort. 40:71-81.

Chase, A.R. and R.T. Poole. 1984. Investigations into the role of fertilizer level and irrigation on growth, quality, and severity of Pythium root rot of Peperomia obtusifolia. J. Amer. Soc. Hort. Sci. 109:619-622.

Chase, A.R. and R.T. Poole. 1987. Effect of fertilizer, temperature, and light level on growth of Syngonium podophyllum 'White Butterfly'. J.. Amer. Soc. Hort. Sci. 112:296-300.

Conover, C.A. and R.T. Poole. 1983. Influence of shade and fertilizer levels on yield of croton stock plants. Proc. Fla. State Hort. Soc. 96:261263.

Coolbaugh, R.C. 1984. Inhibition of ent- kaurene oxidation by cytokinin. J. Plant Growth Reg. 3:97-109.

Florida Dept. of Agriculture. 1989. Foliage facts. Fla. Dept. Agr. December.

Gilliam, C.H., R.L. Shumack, and C.E. Evans. 1983. The effects of slow-release fertilizers on the growth and postproduction performance of Boston fern. HortScience 18:442-444.

Harbaugh, B.K. and G.J. Wilfret. 1979. Gibberellic acid $\left(\mathrm{GA}_{3}\right)$ stimulates flowering in Caladium hortulatum Birdsey. HortScience 1472-73.

Henny, R.J. 1980. Gibberellic acid $\left(\mathrm{GA}_{3}\right)$ induces flowering in Dieffenbachia maculata 'Perfection'. HortScience 15:613.

Poole, R.T. and C.A. Conover. 1988. Storage of philodendron and pathos cuttings. Proc. Fla. State Hort. Soc. 101:313-315.

Poole, R.T., L.S. Osborne, and A.R. Chase. 1984. Pathos. Foliage Dig. 7(2):1-3.

Poole, R.T., C.A. Conover, A.R. Chase, and L.S. Osborne. 1985. Pathos production guide. Foliage Dig. 8(4):4-8.

Veranovetz, R.P. and J.C. Peterson. 1985. Influence of four cultural systems upon geranium stock plant productivity. HortScience 20:703705.

Wang, Y.T. 1987. Effect of warm medium, light intensity, BA, and parent leaf on propagation of golden pathos. HortScience 22:597-599.

Wang, Y.T. and C.A. Boogher. 1987. Effect of stock plant shading, developmental stage and cytokinin on growth and lateral branching of Syngonium podophyllum 'White Butterfly'. Scientia Hon. 33:137-145.

Wang, Y.T. and C.A. Boogher. 1988. Effect of nodal position, cutting length, and root retention on the propagation of golden pathos. HortScience 23:347-349. 